\title{
RADIOCARBON DATING OF BONE OSTEOCALCIN: ISOLATING AND CHARACTERIZING A NON-COLLAGEN PROTEIN
}

\author{
HENRY O. AJIE ${ }^{1}$, ISAAC R. KAPLAN ${ }^{1}$, PETER V. HAUSCHKA ${ }^{2}$, DONNA KIRNER ${ }^{3}$ \\ PETER J. SLOTA, Jr. ${ }^{3}$ and R. E. TAYLOR ${ }^{3}$
}

\begin{abstract}
Osteocalcin, a non-collagen bone-matrix protein, has been examined as a possible source of autochthonous ${ }^{14} \mathrm{C}$ data in fossil bones where collagen has been seriously degraded. Extraction procedures for osteocalcin yield a wellcharacterized product that can be clearly distinguished from collagen. The Gla content indicates that osteocalcin is present in the fossil bones at levels similar to the range present in modern bone. However, it appears to be extracted primarily as proteolytic polypeptide fragments rather than as an intact protein. Concordant ${ }^{14} \mathrm{C}$ determinations are obtained on osteocalcin and gelatin extracts from the same bone when the collagen is relatively well preserved. However, increasing discordances in the ${ }^{14} \mathrm{C}$ values of the osteocalcin and gelatin fractions are associated with reduced concentrations of the gelatin extract in the bone.
\end{abstract}

\section{INTRODUCTION}

Ajie et al. (1990) reported the first set of ${ }^{14} \mathrm{C}$ measurements on osteocalcin, a non-collagen protein, from a series of modern and fossil bones. The purpose of these measurements was to assess the accuracy of osteocalcin ${ }^{14} \mathrm{C}$ age determinations in bone samples that exhibited low or trace levels of collagen. Widely-used methods of chemical pretreatment can yield anomalous ${ }^{14} \mathrm{C}$ ages for fossil bone that has lost $>95 \%$ of its original protein content (Long et al. 1989; Hedges \& Law 1989; Stafford et al. 1987, 1990, 1991; Taylor 1992). Many bones of significant anthropological interest from most tropical and many temperate sites of Pleistocene age have typically been subjected to severe diagenesis, characterized by trace amounts of protein extracts that do not exhibit collagen-like amino-acid patterns (Taylor 1991).

We are concerned with the biochemical nature, and especially the purity, of the osteocalcin fraction on which ${ }^{14} \mathrm{C}$ determinations have been obtained. Thus, we have obtained amino acid composition, radioimmunoassay, electrophoresis and stable isotope data on the osteocalcin extracts.

\section{OSTEOCALCIN}

Osteocalcin is one of several non-collagenous proteins contained in bone. Also known in the biomedical literature as BGP or "Bone Gla protein," osteocalcin was discovered in the early 1970s during a search for the source of the calcium-binding, vitamin-K dependent amino acid, gammacarboxyglutamic acid or Gla (Hauschka, Lian \& Gallop 1975; Price et al. 1976; Hauschka 1977; Hauschka \& Gallop 1977). It is a low molecular weight protein (5200-5900 daltons) with 46-50 amino-acid residues per molecule, which contains 2 or 3 (depending on species) residues of Gla per molecule. Human osteocalcin has 2 Gla residues (Poser et al. 1980). This amino acid is formed within the protein as a result of post-translational carboxylation of specific glutamic acid residues at specific sequence positions. Another protein containing Gla - the Matrix Gla Protein (MGP) with a molecular weight of 9000-11,000 daltons has also been identified in bone. Hauschka et al. (1989) provide the most recent review of the literature on osteocalcin and MGP.

\footnotetext{
${ }^{1}$ Institute of Geophysics and Planetary Physics, University of California, Los Angeles, California 90024 USA ${ }^{2}$ Children's Hospital and Harvard School of Dental Medicine, Boston, Massachusetts 02115 USA

${ }^{3}$ Radiocarbon Laboratory, Department of Anthropology, Institute of Geophysics and Planetary Physics, University of California, Riverside, California 92521 USA
} 
Metabolic functions for osteocalcin may include local control of calcium deposition and removal, a regulatory role in mineral deposition and crystal growth, and possible mediation of the action of vitamin $\mathrm{D}$. Osteocalcin content varies with the degree of bone mineralization within and among organisms; the more mineralized the bone, the higher the osteocalcin content. Because of this, it is most abundant in the midshaft portion of long bones. Mammalian bone generally contains from 1-2 mg of osteocalcin per gram of dry weight of bone. However, human bone contains significantly less; it averages about $0.28 \mathrm{mg}$ of osteocalcin per gram of bone (Hauschka, Lian \& Gallop 1978; Hauschka \& Reid 1978; Hauschka et al. 1989). Averaged over the whole organism, mammalian osteocalcin comprises about $1 \%$ of the total bone protein and some $10-20 \%$ of the noncollagenous bone proteins (Price et al. 1976; Nishimoto \& Price 1979; Hauschka et al. 1989).

The first published proposal to use osteocalcin for the dating of fossil bone was made by Hauschka (1980). Several properties of osteocalcin make it potentially a very useful protein for ${ }^{14} \mathrm{C}$ dating of fossil bones. First, it appears to bind tightly to hydroxyapatite, the major mineral component of bone. In this bound form, the protein should be well protected from biochemical degradation due to the buffering action of hydroxyapatite and the decreased accessibility to exogenous proteinases. Second, Gla has not been detected in a number of potential contaminants; Table 1 lists the materials examined by Hauschka (1977). Although several investigators continue to seek sources of osteocalcin in other organisms, we are not aware of any confirmed reports. If this limited distribution continues to be confirmed, major sources of diagenetic contamination would be minimized.

TABLE 1. Materials in which Gla has not been found at concentrations $>0.2$ residues of Gla/1000 residues of Glu (Hauschka 1977)

\begin{tabular}{ll}
\hline $\begin{array}{l}\text { Calcium-binding Vertebrate Proteins } \\
\text { Thermolysin }\end{array}$ & Collagenase \\
Carp parvalbumin & Brain S-100 protein \\
$\begin{array}{l}\text { Other Vertebrate Proteins } \\
\text { Tubulin }\end{array}$ & Insulin \\
Hyaluronidase & Carbonic anhydrase \\
$\alpha$-Lactalbumin & $\alpha$-Amylase (hog pancreas) \\
$\alpha$-Chymotrypsin & Semen \\
C3 complement & Erythrocyte membrane \\
Pepsin & Spectrin \\
Elastin & Saliva \\
Aldose reductase & Milk \\
Collagen & Procollagen (skin) \\
Plant Proteins & \\
Zein & Spinach, acetone powder \\
Bacterial Cell Cultures & \\
Bacilius subtilis & Escherichia coli \\
Pseudomonas fluorescens & Aerobacter aerogenes \\
Bacteroides melaninogenicus & \\
Reagents & \\
EDTA & Poly-L-glutamic acid \\
\hline
\end{tabular}


Subsequent investigations have extended the usefulness of osteocalcin for geochronological and biogeochemical studies. One question was the degree to which the protein would be protected from chemical degradation on the scale of geologic time. Huq, Tseng and Chapman (1985) detected the osteocalcin antigen in two bones about $4 \mathrm{ka}$ and $7 \mathrm{ka}$ old. Ulrich et al. (1987) examined the osteocalcin content of six bovid bones recovered from geological contexts ranging in age from Miocene $(c a .13 \mathrm{Ma})$ to late Pleistocene ( $c a .12 \mathrm{ka}$ ) and found that the osteocalcin antigen as well as its Gla residue remained detectable in all of the samples.

\section{EXTRACTION AND PURIFICATION PROCEDURES}

Bone samples were first cleaned by ultrasonication in an ice-cold Tris-buffered protease inhibitor solution (TPIC) (Gundberg et al. 1984), then rinsed several times with ice-cold distilled water and freeze-dried. The dry bone was then powered in liquid nitrogen with a diamond mortar to a size less than $710 \mu$. The powder was then homogenized in ice-cold TPIC $(1 \mathrm{gm} / 20 \mathrm{ml})$ for $30 \mathrm{~min}$ and allowed to settle. Decanting and rehomogenization with distilled water was continued until the supernatant was clear and colorless.

Гwo methods were examined to extract and purify an osteocalcin fraction: one using EDTA (Gundberg et al. 1984) and a modification of a method using formic acid (Poser et al. 1980). Since both methods appeared to produce a comparable product, and the formic acid method avoids the possibility of incomplete EDTA removal, we used the latter technique to extract the osteocalcin on which the initial ${ }^{14} \mathrm{C}$ and other analytical data were obtained.

The bone was demineralized in $20 \%$ formic acid $\left(10 \mathrm{ml} \mathrm{gm}^{-1}\right.$ of bone) followed by dialysis (Spectrapor 1 membrane tubing, mol. wt. cutoff 6000-8000) against deionized water for four days at $4^{\circ} \mathrm{C}$ with daily changes of water. (It has been experimentally determined that the highly charged osteocalcin molecule behaves hydrodynamically as a protein of 10,000 to $15,000 \mathrm{~mol}$. wt. during dialysis extraction.) The content of the dialysis tubing was centrifuged and the supernatant reduced to a volume of $20 \mathrm{ml}$ by freeze-drying. This was followed by gel filtration of the soluble extract on sephacryl S-200 in $6 \mathrm{M}$ Guanidine $\mathrm{HCl}$. Elution of osteocalcin was monitored by absorbance at $276 \mathrm{~nm}$. The pooled osteocalcin fraction was freeze dried, dissolved in $0.07 \mathrm{M} \mathrm{NH}_{4} \mathrm{HCO}_{3}(1 \mathrm{mg}$ $\mathrm{ml}^{-1}$ ) and eluted from a DEAE ion exchange column with a $700 \mathrm{ml}$ linear gradient of $0.07 \mathrm{M}$ to $0.7 \mathrm{M} \mathrm{NH}_{4} \mathrm{HCO}_{3}$. Fractions of $5 \mathrm{ml}$ were collected and the protein was monitored by $\mathrm{A}_{276}$. The pooled osteocalcin fraction was reduced to a volume of $10 \mathrm{ml}$ by freeze-drying, dialyzed against deionized water at $4^{\circ} \mathrm{C}$ for four days with daily changes of water, and subsequently freeze-dried to yield osteocalcin. We took appropriate precautions to avoid intersample contamination by using separate columns for modern and fossil samples, extensive column washing and isotopic and amino-acid analyses of blank column eluent buffers.

To characterize biochemically the formic acid-extracted osteocalcin fraction, amino-acid composition, radioimmunoassay and preliminary electrophoresis data were obtained on extracts from human and moa bone samples. Table 2 presents the Gla and osteocalcin content of five human bones, while Figure 1 illustrates dilution curves comparing radioimmunoassay data from monkey (M. fascicularis) (Hauschka, Carr \& Biemann 1983), a modern human and a human fossil bone (HA-104) from the Haverty site (Haverty skeleton 4). HA-104 exhibited a dilution curve parallel to that of the modern bone control indicating strong identity of the ancient antigen to modern osteocalcin. The Gla content indicates that it is present in the fossil bones at levels similar to the range present in modern bone. However, the radioimmunoassay data, which detect only intact osteocalcin - not reacting to proteolytic fragments of the native protein - indicate that the fossil human bones retained only a fraction of the in vivo osteocalcin content of modern bone. The range 
TABLE 2. Gla and Osteocalcin Content of Fossil Human Bone

\begin{tabular}{ccc}
\hline Sample no. & Gla/Glu* & $\begin{array}{c}\text { Osteocalcin } \\
\text { content** }\end{array}$ \\
\hline HA-100 & 3.71 & 3.3 \\
HA-103 & 5.26 & 5.1 \\
HA-101 & 2.99 & 2.6 \\
HA-102 & 3.54 & 5.2 \\
HA-104 & 4.85 & 17.4 \\
\hline
\end{tabular}

*Expressed as residues Gla/1000 residues Glu of alkaline-hydrolyzed whole bone powder; standard bovine Gla concentration $=5.31$; modern human Gla concentration ranges from 2.5 to 8.5 depending on bone and location in body (Hauschka 1977 and unpublished data).

**Expressed as \% of modern human where modern human osteocalcin content is set at $0.28 \mathrm{mg} / \mathrm{g}$ bone (Hauschka et al. 1989).

${ }^{\dagger}$ See Fig. 1.

\section{Bone Extract ( $\mu \mathrm{g} /$ tube)}

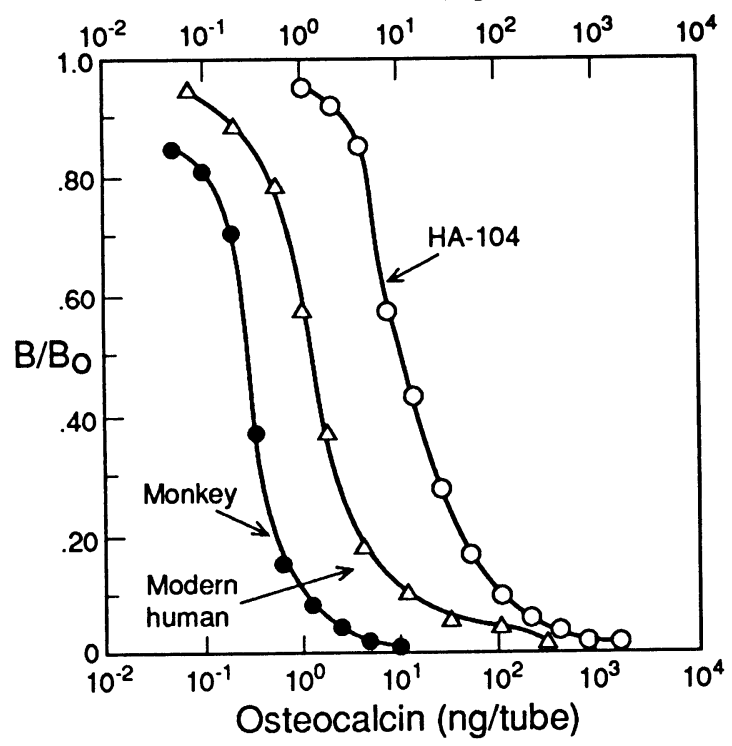

Fig. 1. Radioimmunoassay (RIA) of modern human bone $(\Delta)$, modern monkey (M. fascicularis) bone $(\bullet)$ and HA-104, fossil human bone (O) using non-equilibrium technique described in Gundberg et al. (1984). Primary antiserum was rabbit antibovine osteocalcin used at a final dilution of 12,600-fold. Extracts were serially diluted in assay buffer and assayed over a wide range corresponding to $0.05-2000 \mu \mathrm{g}$ bone/tube (upper abscissa). Immunoprecipitation with goat antirabbit IgG second antibody was followed by centrifugation, washing of pellets and gamma counting. Data are expressed as the quotient $\mathrm{B} / \mathrm{B}_{0}$, where $\mathrm{B}$ is designated as the amount of ${ }^{125}$ I-osteocalcin, specifically bound to antibody, and $B_{0}$ is the value of $B$ in the absence of added unlabeled osteocalcin. Monkey osteocalcin standard (lower abscissa) gave a midpoint $\mathrm{B} / \mathrm{B}_{\mathrm{o}}=0.5$ at $0.24 \mathrm{ng} /$ tube, with an interassay variation of $10 \%$.

in osteocalcin content exhibited by the fossil bones suggests that diagenetic conditions may, in part, control the amount of intact osteocalcin that can be extracted.

The amino-acid composition of the osteocalcin isolated from the fossil bones is clearly similar to modern human osteocalcin (Poser et al. 1980) and can be clearly distinguished from collagen. No hydroxyproline was found in the osteocalcin extracts of any of the human fossil bones examined. Further, preliminary data from electrophoresis indicate that the extraction procedures applied to fossil bone yield only a low molecular weight protein of 6000-15,000 daltons. This appears to exclude the presence of collagen proteins in the purified osteocalcin fraction.

To examine the relationship between the stable isotope data of the osteocalcin and gelatin fractions, aliquots were combusted using the methods of Minagawa, Winter and Kaplan (1984), and the resulting $\mathrm{CO}_{2}$ and nitrogen were analyzed for $\delta^{13} \mathrm{C}$ (Fig. 2) and $\delta^{15} \mathrm{~N}$ values (Fig. 3). Shifts in stable 
isotope values appear to correlate with decreased gelatin concentrations at or below $1 \%$ of modern bone values. The changes in stable isotope values may correlate with partial elimination of the most soluble amino-acid residues and peptide fragments derived from the poly-peptide chains of these samples (Tuross, Fogel \& Hare 1988), or perhaps reflect terrestrial soil contamination (Ajie et al. 1991).
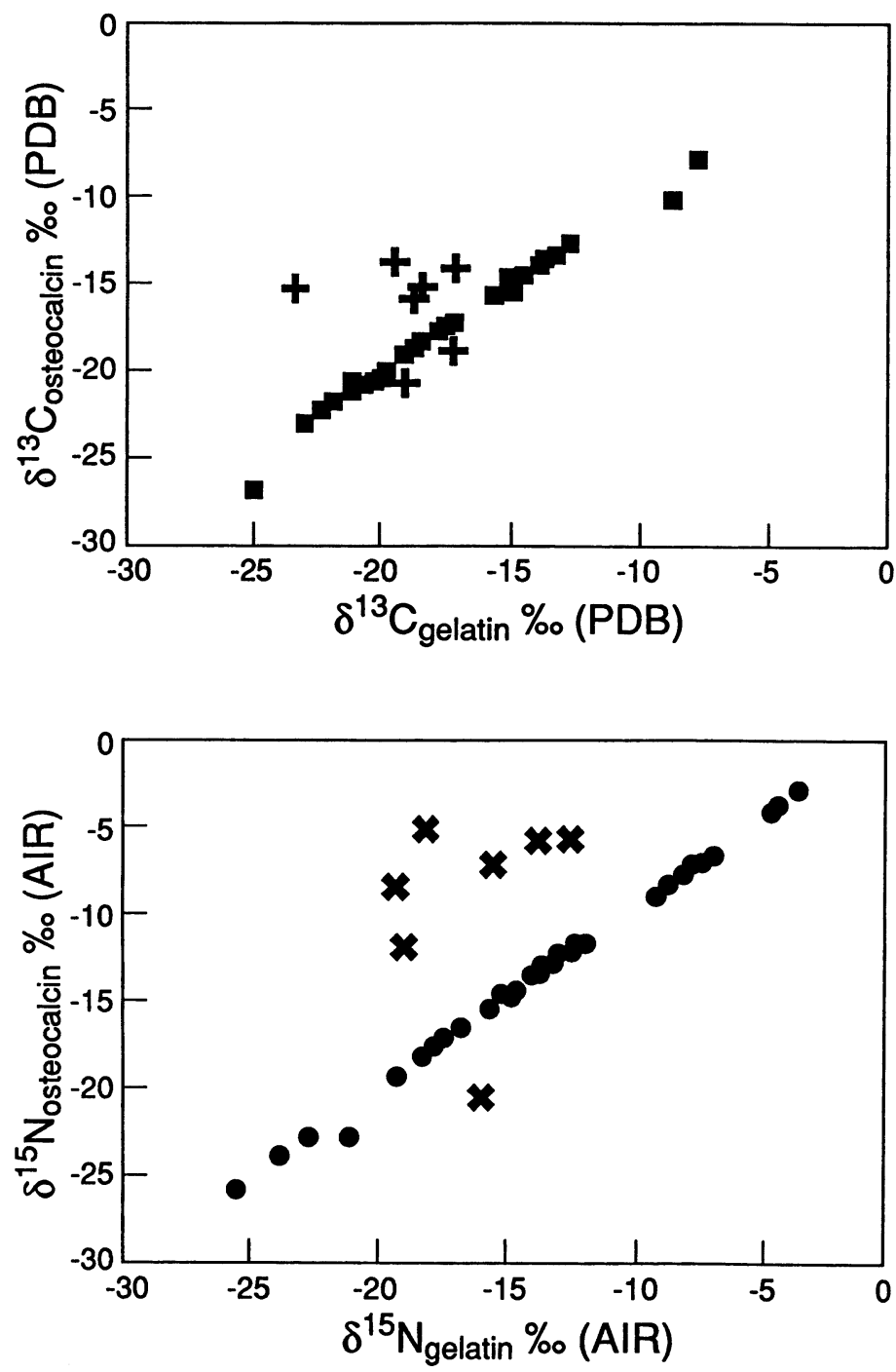

Fig. 2. Stable carbon isotope ratios of gelatin $v s$. osteocalcin from 50 modern and fossil bone samples. "+" indicates a bone with gelatin content of $<1 \%$.

\section{RADIOCARBON DETERMINATIONS ON OSTEOCALCIN}

To provide modern controls, Table 3 presents elemental, stable isotope, and amino-acid compositional data on gelatin and osteocalcin extracts from the series of modern human bones. Gelatin was extracted using methods outlined in DeNiro and Epstein (1981) and Schoeninger and DeNiro (1984). This involves washing in TPIC, solubilizing in $1 \mathrm{mM} \mathrm{HCl}$ for $10 \mathrm{~h}$ at $90^{\circ} \mathrm{C}$, filtering and lyophilizing. As expected, the elemental carbon/nitrogen $(\mathrm{C} / \mathrm{N})$, hydroxyproline (Hyp), glycine/ 
glutamic (Gly/Glu) acid and glycine/aspartic acid (Gly/Asp) ratios reflect the presence of intact collagen. While the gelatin (collagen) concentration moderately varied in these samples, the osteocalcin concentration does not vary significantly.

TABLE 3. Biogeochemical data on gelatin (collagen) and osteocalcin fractions of modern human bone

\begin{tabular}{|c|c|c|c|c|c|c|c|c|c|c|c|}
\hline \multirow[b]{2}{*}{$\begin{array}{c}\text { Sample } \\
\text { no. }\end{array}$} & \multicolumn{7}{|c|}{ Gelatin } & \multicolumn{4}{|c|}{ Osteocalcin } \\
\hline & $\mathrm{Wt} \%$ & $\mathrm{C} / \mathrm{N}^{*}$ & $\begin{array}{c}\delta^{13} \mathrm{C}^{* *} \\
(\% 0)\end{array}$ & $\begin{array}{l}\delta^{15} \mathrm{~N} \\
(\% 0)\end{array}$ & $\begin{array}{c}\text { Hyp }^{\dagger} \\
(\mathrm{R} / 1000)\end{array}$ & $\begin{array}{l}\text { Gly } /^{\star} \\
\text { Glu }\end{array}$ & $\begin{array}{l}\text { Gly/s } \\
\text { Asp }\end{array}$ & $\mathrm{Wt} \%$ & $\mathrm{C} / \mathrm{N}^{*}$ & $\begin{array}{c}\delta^{13} \mathrm{C}^{* *} \\
(\% 0)\end{array}$ & $\begin{array}{l}\delta^{15} \mathrm{~N} \\
(\%)\end{array}$ \\
\hline CGH-512 & 19.9 & 3.3 & -19.6 & +10.3 & 86 & 4.7 & 7.1 & .25 & 4.2 & -20.0 & +10.3 \\
\hline CGH-513 & 16.1 & 3.1 & -17.4 & +7.8 & 85 & 4.7 & 7.1 & .26 & 4.2 & -17.7 & +7.9 \\
\hline CGH-514 & 12.9 & 3.2 & -18.6 & +8.4 & 85 & 4.7 & 7.2 & .25 & 4.2 & -18.7 & +8.5 \\
\hline CGH-511 & 8.9 & 3.1 & -17.0 & +10.0 & 85 & 4.7 & 7.2 & .20 & 4.2 & -17.1 & +10.3 \\
\hline CGH.510 & 7.5 & 3.1 & -20.9 & +10.3 & 85 & 4.7 & 7.2 & .24 & 4.1 & -20.6 & +10.4 \\
\hline
\end{tabular}

*Carbon/nitrogen ratio

${ }^{* *} \delta^{13} \mathrm{C}$ PDB; $\delta^{15} \mathrm{~N}$ AIR

${ }^{\dagger}$ Hydroxyproline composition in residues $/ 1000$

${ }^{\ddagger}$ Glycine/glutamic acid ratio

Glycine/aspartic acid ratio

A previous report presented ${ }^{14} \mathrm{C}$ and compositional data obtained on a series of fossil bones (Ajie et al. 1990: Table 2). In these samples, although gelatin content ranged from about $12 \%$ to $<0.2 \%$, osteocalcin concentration varied relatively little. What variation we observed was associated with differences between human and moa bone; there was virtually no difference in osteocalcin content measured in human bone even though the ages ranged from about $3 \mathrm{ka}$ to almost $25 \mathrm{ka}$. In our view, these data supported the view that hydroxyapatite protects the osteocalcin from major diagenesis.

To examine variability in gelatin and osteocalcin ${ }^{14} \mathrm{C}$ values in a suite of fossil bones of assumed similar age but with significant variability in preservation of the gelatin/collagen fraction, we analyzed human skeletons from the Haverty (Angeles Mesa) site, Los Angeles County, California. A recent summary of analytical evidence concluded that the Haverty skeletons were interred over a relatively short time interval between 4 and $5{ }^{14} \mathrm{C}$ ka BP. This conclusion was, in part, based on ${ }^{14} \mathrm{C}$ values previously obtained on three of the Haverty skeletons (Brooks et al. 1991).

Table 4 lists the ${ }^{14} \mathrm{C}$ data obtained on gelatin and osteocalcin fractions obtained on 6 bones from 5 Haverty skeletons. For Haverty skeleton 1, both the gelatin and osteocalcin values are consistent with previous ${ }^{14} \mathrm{C}$ values obtained on this skeleton. However, as the percentage yield of the gelatin extract decreases and the $\mathrm{C} / \mathrm{N}$ ratio progressively diverges from modern bone in other Haverty skeletons, there appears to be a trend for the discordance between the gelatin and osteocalcin ${ }^{14} \mathrm{C}$ values to increase. This suggests the possibility of a progressive contamination of the collagen in these samples. There is also a divergence from the pattern exhibited in modern bone in the stable isotope values of the gelatin and osteocalcin fractions. This is especially the case with regard to Haverty skeleton 4 (HA-104). In view of the fact that the osteocalcin ${ }^{14} \mathrm{C}$ age on Haverty skeleton 4 represents an age in excess of $12 \mathrm{ka}$, i.e., potentially of pre-Clovis age, while other associated geological, archaeological and ${ }^{14} \mathrm{C}$ data indicate a much younger age, we will continue our studies with regard to the isotopic integrity of the gelatin and osteocalcin extracts obtained from all of the Haverty human skeletal samples, including HA-104. 


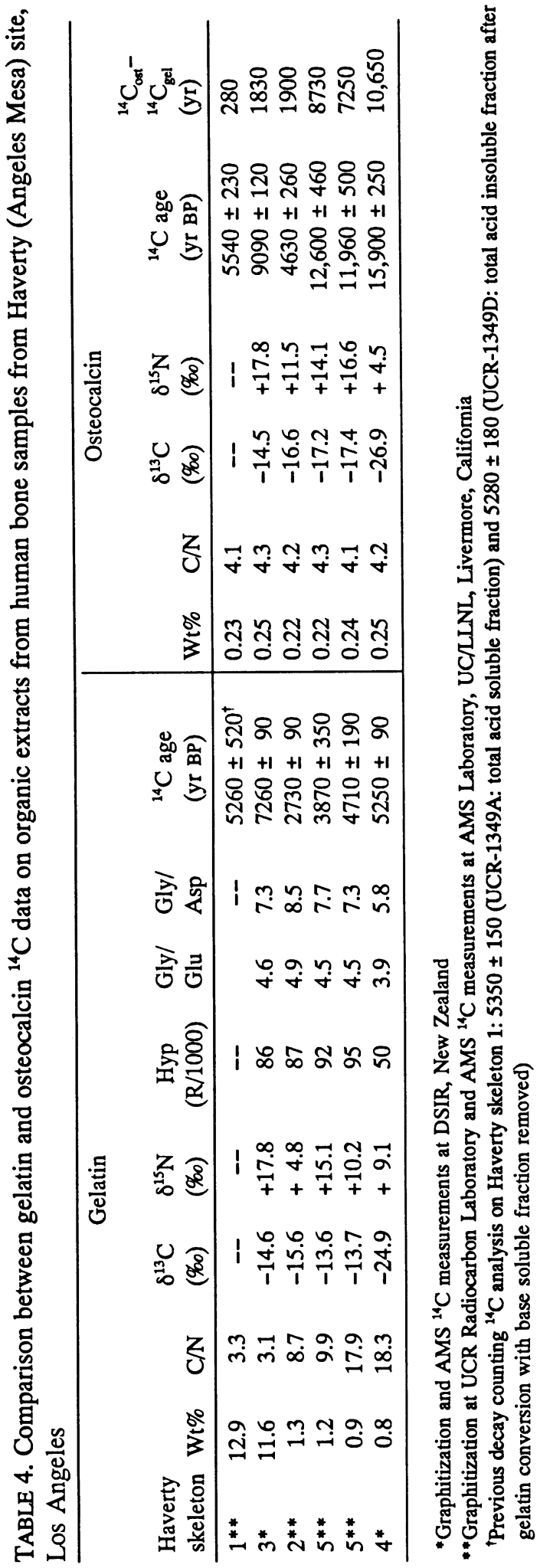




\section{APPLICATION TO DATING OF MACHU PICCHU HUMAN SKELETONS}

Excavations in 1911 at the site of Machu Picchu (130.' , $\left.72^{\circ} 32^{\prime} \mathrm{W}\right)$ in the Southern Andes of Peru revealed a series of graves containing human skeletons and associated grave goods. The skeletal and artifact assemblage from these excavations were subsequently housed at Yale University. Although the artifacts from Machu Picchu represent only Inca and early Colonial period materials, Eaton (1916) suggested that the site also contained a pre-Inca occupation. This interpretation has been disputed by later investigators.

Radiocarbon determination on bone collagen from five Machu Picchu human skeletons from the Yale collection yielded ages ranging from 640 to 2050 BP (Berger et al. 1988). We have obtained AMS ${ }^{14} \mathrm{C}$ ages on gelatin and osteocalcin fractions from these five skeletons (Table 5). The collagen appears to be well preserved as evidenced by the weight percent and $\mathrm{C} / \mathrm{N}$ ratios of the extractable gelatin. Our ${ }^{14} \mathrm{C}$ data and particularly the concordant gelatin/osteocalcin values indicate that these skeletons are not earlier than the Inca period. This conclusion is entirely consistent with the current views of specialists in Andean studies concerning the dating of Machu Picchu materials (Christopher B. Donnan, personal communication, 1991). Because of the statistical ranges associated with the dates and the post-16th century de Vries effects, the skeletons could be much younger.

TABLE 5. Radiocarbon Determinations on Bone Samples from Machu Picchu, Peru

\begin{tabular}{lccc}
\hline $\begin{array}{l}\text { Bone } \\
\text { (Yale) }\end{array}$ & Collagen* & $\frac{{ }^{14} \mathrm{C} \text { age }(\mathrm{yr} \mathrm{BP})}{\text { Gelatin** }^{*}}$ & Osteocalcin** $^{* *}$ \\
\hline 3175 & $855 \pm 365$ (UCLA-2702B) & $340 \pm 150$ (CAMS-822) & $310 \pm 150$ (CAMS-821) \\
3211 & $1485 \pm 185$ (UCLA-2702D) & $230 \pm 130$ (CAMS-816) & $230 \pm 120$ (CAMS-815) \\
3212 & -- & $320 \pm 150$ (CAMS-818) & $350 \pm 100$ (CAMS-817) \\
3239 & $850 \pm 325$ (UCLA-2702F) & $240 \pm 120$ (CAMS-820) & $350 \pm 90$ (CAMS-819) \\
3248 & $640 \pm 180$ (UCLA-2702G) & $420 \pm 130$ (CAMS-824) & $300 \pm 100$ (CAMS-823) \\
\hline
\end{tabular}

\footnotetext{
*Berger et al. (1988) identifies the organic extract as collagen.

**This report; AMS analysis at Center for Acclerator Mass Spectrometry, University of California/Lawrence Livermore National Laboratory AMS Laboratory (J. S. Vogel, personal communication). Estimated $\delta^{13} \mathrm{C}=-20 \%$.
}

\section{CONCLUSIONS}

Osteocalcin is a non-collagen protein that holds promise for obtaining reliable ${ }^{14} \mathrm{C}$ age estimates on bone in which collagen concentrations have been seriously depleted. Using bones with a wide range of collagen preservation, we have obtained ${ }^{14} \mathrm{C}$ measurements on gelatin and osteocalcin extracts and have measured other indices of the biogeochemical status of the extracted fractions. In bones of presumed similar age, serious discordance in ${ }^{14} \mathrm{C}$ ages of gelatin and osteocalcin fractions appear to be accompanied by a decrease in gelatin content in the bone and anomalies in the stable isotope data.

Amino-acid composition, radioimmunoassay and electrophoresis studies of osteocalcin fractions indicate that the osteocalcin extraction procedures exclude collagen. The Gla content indicates that Gla is present in the fossil bones at levels similar to modern bone. However, the extractable osteocalcin appears primarily as proteolytic polypeptide fragments, rather than intact protein. The range in osteocalcin content in the fossil bones suggests that diagenetic conditions may control the amount of intact osteocalcin that can be extracted and its degree of fragmentation. 


\section{ACKNOWLEDGMENTS}

The UCR Radiocarbon Laboratory (RET) is supported by the National Science Foundation, BNS-9119958 (Anthropology [Archaeometry] Program). Additional support by the University of California/Lawrence Livermore National Laboratory (UC/LLNL) AMS Laboratory and Dean Brian P. Copenhaver, UCR College of Humanities and Social Sciences, is also gratefully acknowledged. The research was also supported in part by USPHS-NIH grant AR 34078 (PVH). We acknowledge the helpful collaboration of G. Pascarelli (Children's Hospital, Boston), J. Davis, I. Proctor, J. Southon and J. S. Vogel (UC/LLNL AMS Laboratory), as well as the comments of Richard Gillespie and an anonymous reviewer on an earlier draft of this paper. This is contribution 91/9 of the Institute of Geophysics and Planetary Physics, University of California, Riverside.

\section{REFERENCES}

Ajie, H. O., Hauschka, P. V., Kaplan, I. R. and Sobel, H. 1991 Comparison of bone collagen and osteocal$\mathrm{cin}$ for determination of radiocarbon ages and paleodietary reconstruction. Earth and Planetary Science Letters 107: 380-388.

Ajie, H. O., Kaplan, I. R., Slota, P. J., Jr. and Taylor, R. E. 1990 AMS radiocarbon dating of bone osteocalcin. In Yiou, F. and Raisbeck, G. M., eds., Proceedings of the 5th International Conference on Accelerator Mass Spectrometry. Nuclear Instruments and Methods B52: 433-437.

Berger, R., Chohfi, R., Zegarra, A. V., Yepez, W. and Carrasco, O. F. 1988 Radiocarbon dating Machu Picchu, Peru. Antiquity 62: 707-710.

Brooks, S., Brooks, R. H., Kennedy, G. E., Austin, J., Firby, J. R., Payen, L. A., Prior, C. A., Slota, P. J., Jr. and Taylor, R. E. 1991 The Haverty human skeletons: Morphological, depositional and geochronological characteristics. Journal of California and Great Basin Anthropology 12: 60-83.

DeNiro, M. F. and Epstein, S. 1981 Influence of diet on the distribution of nitrogen isotopes in animals. Geochimica et Cosmochimica Acta 45: 341-351.

Eaton, G. F. 1916 The collection of osteological materials from Machu Picchu. Connecticut Academy of Arts and Sciences Memoirs 5.

Gundberg, C. M., Hauschka, P. V., Lian, J. B. and Gallop, P. M. 1984 Osteocalcin: Isolation, characterization and detection. Methods in Enzymology 107: 516-544.

Hauschka, P. V. 1977 Quantitative determination of gamma-carboxyglutamic acid in proteins. Analytical Biochemistry 80: 212-223.

1980 Osteocalcin: A specific protein of bone with potential for fossil dating. In Hare, P. E., Hoering, T. C. and King, K., eds., Biogeochemistry of Amino Acids. New York, Wiley: 75-82.

Hauschka, P. V., Carr, S. A. and Biemann, K. 1983 Primary structure of monkey osteocalcin. Biochemistry 21: 638-642.

Hauschka, P. V. and Gallop, P. M. 1977 Purification and calcium-binding properties of osteocalcin, the gamma carboxyglutamate-containing protein of bone.
In Wasserman, R. H., Corradino, R. A., Carafoli, E., Kretsinger, R. H., MacLennan, D. H. and Siegel, F. L., eds., Calcium Binding Proteins and Calcium Functions. Amsterdam, Elsevier/North Holland: 338347.

Hauschka, P. V., Lian, J. B., Cole, D. E. C. and Gundberg, C. M. 1989 Osteocalcin and matrix Gla protein: vitamin K-dependent proteins in bone. Physiological Review 69: 990-1047.

Hauschka, P. V., Lian, J. B. and Gallop, P. M. 1975 Direct identification of the calcium-binding amino acid gamma-carboxyglutamate in mineralized tissue. Proceedings of the National Academy of Science (USA) 72: 3925-3929.

1978 Vitamin K and mineralization. Trends in Biochemical Science 3: 75-78.

Hauschka, P. V. and Reid, M. L. 1978 Vitamin Kdependence of a calcium-binding protein containing gamma-carboxyglutamic acid in chicken bone. Journal of Biological Chemistry 253: 9063-9068.

Hedges, R. E. M and Law, I. A. 1989 The radiocarbon dating of bone. Applied Geochemistry 4: 249-253.

Huq, N. L., Tseng, A. and Chapman, G. 1985 Partial amino acid sequence of osteocalcin from an extinct species of Ratite bird. Biochemistry International 21: 491-496.

Long, A., Wilson, A. T., Ernst, R. D., Gore, B. H. and Hare, P. E. 1989 AMS radiocarbon dating of bones at Arizona. In Long, A. and Kra, R. S., eds., Proceedings of the 13 th International ${ }^{14} \mathrm{C}$ Conference. Radiocarbon 31(3): 231-238.

Minagawa, M., Winter, D. A. and Kaplan, I. R. 1984 Comparison of Kjeldahl and combustion methods for measurement of nitrogen isotope ratios in organic matter. Analytical Chemistry 56: 1859-1861.

Nishimoto, S. K. and Price, P. A. 1979 Proof that the gamma-carboxyglutamic acid containing bone protein is synthesized in calf bone. Journal of Biological Chemistry 254: 437-441.

Poser, J. W., Esch, F., Ling, N. C. and Price, P. A. 1980 Isolation and sequence of the vitamin K-dependent protein from human bone. Journal of Biological Chemistry 225: 8685-8691. 
Price, A. S., Otsuka, J. W., Poser, J. W., Gristaponis, J. and Raman, N. 1976 Characterization of a gammacarboxyglutamic acid protein from bone. Proceedings of the National Academy of Science 73: 1447-1451.

Schoeninger, M. J. and DeNiro, M. J. 1984 Nitrogen and carbon isotopic composition of bone collagen from marine and terrestrial animals. Geochimica et Cosmochimica Acta 48: 625-639.

Stafford, T. W., Jr., Jull, A. J. T., Brendel, K., Duhamel, R. C. and Donahue, D. 1987 Study of bone radiocarbon dating accuracy at the University of Arizona NSF accelerator facility for radioisotope analysis. Radiocarbon 29(1): 24-44.

Stafford, T. W., Jr., Hare, P. E., Currie, L., Jull, A. J. T. and Donahue, D. J. 1990 Accuracy of North American human skeleton ages. Quaternary Research 34: 111-120.

Stafford, T. W., Jr., Hare, P. E., Currie, L., Jull, A. J. T. and Donahue, D. J. 1991 Accelerator radiocarbon dating at the molecular level. Journal of Archaeological Science 18: 35-71.
Taylor, R. E. 1991 Frameworks for dating the Late Pleistocene peopling of the Americas. In Dillehay, T. D. and Meltzer, D. J., eds., The First Americans: Search and Research. Boca Raton, Florida, CRC Press: 77-112.

1992 Radiocarbon dating of bone: To collagen and beyond. In Taylor, R. E., Long, A. and Kra, R. S., eds., Radiocarbon After Four Decades: An Interdisciplinary Perspective. New York, SpringerVerlag: 375-402.

Tuross, N., Fogel, M. L. and Hare, P. E. 1988 Variability in the preservation of the isotopic composition of collagen from fossil bone. Geochimica et Cosmochimica Acta 52: 929-935.

Ulrich, M. M. W., Perizonius, W. R. K., Spoor, C. F., Sandberg, P. and Vermeer, C. 1987 Extraction of osteocalcin from fossil bones and teeth. Biochemical and Biophysical Research Communication 149: 712-719. 